\title{
Commentary Lymphocytes, apoptosis and sepsis: making the jump from mice to humans
}

\author{
John D Lang ${ }^{1,2}$ and Gustavo Matute-Bello ${ }^{3}$
}

\author{
1The VA Puget Sound HealthCare System, Seattle, WA 98108, USA \\ 2Department of Anesthesiology, University of Washington, Seattle, WA 98195, USA \\ 3Division of Pulmonary and Critical Care Medicine, Center for Lung Biology, Department of Medicine, University of Washington, Seattle, WA 98109, \\ USA
}

Corresponding author: Gustavo Matute-Bello

Published: 12 January 2009

Critical Care 2009, 13:109 (doi:10.1186/cc7144)

This article is online at http://ccforum.com/content/13/1/109

(c) 2009 BioMed Central Ltd

See related research by Weber et al., http://ccforum.com/content/12/6/R128

\begin{abstract}
Sepsis is an important clinical problem with a mortality rate of $20 \%$ to $30 \%$. Lymphocyte apoptosis has been recognized as an important step in the pathogenesis of experimental sepsis, by inducing a state of 'immune paralysis' that renders the host vulnerable to invading pathogens. The importance of lymphocyte apoptosis in human disease is now confirmed by Weber and colleagues, who demonstrate extensive apoptosis in circulating lymphocytes from patients with severe sepsis. Weber and colleagues' data set the basis for further studies aimed at modulating lymphocyte apoptosis in sepsis.
\end{abstract}

Lymphocyte apoptosis has been increasingly recognized as an important step in the pathogenesis of sepsis, by inducing a state of 'immune paralysis' that renders the host vulnerable to invading pathogens [1]. Sepsis is an important clinical problem, affecting more than 700,000 people each year in the United States alone, of whom 20\% to 30\% die [2]. The costs associated with sepsis amount to approximately $\$ 17$ billion per year [3]. Clearly, sepsis is a major health problem and novel therapeutic strategies are required.

The traditional paradigm has been that sepsis results from an uncontrolled inflammatory response. This paradigm led to the development of agents aimed at blocking key mediators of inflammation, such as bacterial lipopolysaccharide, interleukin-1, and/or tumor necrosis factor- $\alpha$ among others. However, when many of these agents were tested in large phase III randomized controlled trials they failed to demonstrate a beneficial effect [4-6]. Thus, therapeutic strategies aimed at suppressing inflammation in sepsis have been disappointing.

Over the past decade, studies in experimental models and in patients suggested that the immune response of sepsis follows a biphasic pattern, with an initial 'hyperinflammatatory' phase characterized by high levels of pro-inflammatory cytokines, and a second phase characterized by decreased responsiveness of immune cells to inflammatory stimuli - the 'immunoparalysis' phase $[7,8]$. The immunoparalysis phase is an extremely vulnerable period when patients are at particular risk from invading bacteria. The mechanism for this immune paralysis appears to involve apoptosis of immune cells, in particular lymphocytes.

In a seminal study, Wang et al. [9] found that the intraperitoneal injection of Gram-negative bacteria to mice was followed by apoptosis of CD4+CD8+ lymphocytes in the thymus. Hotchkiss et al. $[10,11]$ used a murine model of cecal ligation and puncture to show that lymphocyte apoptosis also involves lymphocytes from the spleen and most other vital organ systems, and later demonstrated that extensive lymphocyte apoptosis is also present in humans with sepsis. Studies using loss-of-function approaches suggested that the mechanisms of lymphocyte apoptosis in sepsis involve both the receptor-mediated and the mitochondrial pathways of apoptosis, with the later playing the predominant role (reviewed in [12]). Weber et al. [1] now extend these laboratory observations to the bedside, by demonstrating accelerated apoptosis in circulating lymphocytes (CD4, CD8 and CD19) from patients with severe sepsis, but not in non-septic, critically ill patients. This study is important because it confirms a pattern of activation of $\mathrm{Bcl}-2$ family members predicted by animal studies, and sets the basis for further studies aimed at modulating lymphocyte apoptosis in sepsis.

One particularly interesting finding in Weber and colleagues' study is that the pro-apoptotic molecule Bim was markedly upregulated in the lymphocytes of patients with severe sepsis. This is important because, of the different components of the apoptosis cascade that have been tested in 
animal models (FADD, Bid, Bcl2, caspases), only deletion of $\mathrm{Bim}$ is associated with complete protection from apoptosis [13]. However, it is important to note that blockade of lymphocyte apoptosis is not always protective in sepsis. For example, septic mice lacking MyD88 have decreased lymphocyte apoptosis but a significant increase in mortality [14]. MyD88 is an important proximal component of the main pathogen recognition pathways, suggesting that inhibition of lymphocyte apoptosis is protective only when the ability of the host to identify and respond to pathogens is preserved.

The study has some caveats. Patients were enrolled 4 hours after presentation, which may have been too early in the hospital course to catch the period of maximal apoptosis. Also, information on the effects of severe sepsis on the receptor-mediated pathway of apoptosis, particularly FADD and caspase 8 , would have been interesting.

In summary, the study by Weber and colleagues reaffirms and advances our knowledge of specific pathways involved in lymphocyte apoptosis in patients suffering from severe sepsis, raising hopes for potential therapeutic targets that improve mortality in this patient population.

\section{Competing interests}

The authors declare that they have no competing interests.

\section{References}

1. Weber SU, Schewe JC, Lehmann LE, Muller S, Book M, Klaschik $\mathrm{S}$, Hoeft A, Stuber F: Induction of Bim and Bid gene expression during accelerated apoptosis in severe sepsis. Crit Care 2008, 12:R128.

2. Martin GS, Mannino DM, Eaton S, Moss M: The epidemiology of sepsis in the United States from 1979 through 2000. N Engl J Med 2003, 348:1546-1554.

3. Angus DC, Linde-Zwirble WT, Lidicker J, Clermont G, Carcillo J, Pinsky MR: Epidemiology of severe sepsis in the United States: analysis of incidence, outcome, and associated costs of care. Crit Care Med 2001, 29:1303-1310.

4. Opal Opal SM, Fisher CJ Jr, Dhainaut JF, Vincent JL, Brase R, Lowry SF, Sadoff JC, Slotman GJ, Levy H, Balk RA, Shelly MP, Pribble JP, LaBrecque JF, Lookabaugh J, Donovan H, Dubin H, Baughman R, Norman J, DeMaria E, Matzel K, Abraham E, Seneff $\mathrm{M}$ : Confirmatory interleukin-1 receptor antagonist trial in severe sepsis: a phase III, randomized, double-blind, placebocontrolled, multicenter trial. The Interleukin-1 Receptor Antagonist Sepsis Investigator Group. Crit Care Med 1997, 25: 1115-1124.

5. Angus DC, Birmingham MC, Balk RA, Scannon PJ, Collins D, Kruse JA, Graham DR, Dedhia HV, Homann S, Maclntyre N: E5 murine monoclonal antiendotoxin antibody in gram-negative sepsis: a randomized controlled trial. E5 Study Investigators. JAMA 2000, 283:1723-1730.

6. Abraham E, Laterre PF, Garbino J, Pingleton S, Butler T, Dugernier T, Margolis B, Kudsk K, Zimmerli W, Anderson P, Reynaert $M$, Lew D, Lesslauer W, Passe S, Cooper P, Burdeska A, Modi M, Leighton A, Salgo M, Van der Auwera P; Lenercept Study Group: Lenercept (p55 tumor necrosis factor receptor fusion protein) in severe sepsis and early septic shock: a randomized, double-blind, placebo-controlled, multicenter phase III trial with 1,342 patients. Crit Care Med 2001, 29:503-510.

7. Volk HD, Reinke P, Krausch D, Zuckermann H, Asadullah K, Müller JM, Döcke WD, Kox WJ: Monocyte deactivation - rationale for a new therapeutic strategy in sepsis. Intensive Care Med 1996, 22(Suppl 4):S474-S481.
8. Döcke WD, Randow F, Syrbe U, Krausch D, Asadullah K, Reinke $\mathrm{P}$, Volk HD, Kox W: Monocyte deactivation in septic patients: restoration by IFN-gamma treatment. Nat Med 1997, 3:678681.

9. Wang SD, Huang KJ, Lin YS, Lei HY: Sepsis-induced apoptosis of the thymocytes in mice. J Immunol 1994, 152:5014-5021.

10. Hotchkiss RS, Swanson PE, Cobb JP, Jacobson A, Buchman TG, Karl IE: Apoptosis in lymphoid and parenchymal cells during sepsis: findings in normal and T- and B-cell-deficient mice. Crit Care Med 1997, 25:1298-1307.

11. Hotchkiss RS, Tinsley KW, Swanson PE, Schmieg RE Jr, Hui JJ, Chang KC, Osborne DF, Freeman BD, Cobb JP, Buchman TG, Karl IE: Sepsis-induced apoptosis causes progressive profound depletion of $B$ and $C D 4+T$ lymphocytes in humans. $J$ Immunol 2001, 166:6952-6963.

12. Hotchkiss RS, Nicholson DW: Apoptosis and caspases regulate death and inflammation in sepsis. Nat Rev Immunol 2006, 6:813-822.

13. Chang KC, Unsinger J, Davis CG, Schwulst SJ, Muenzer JT, Strasser A, Hotchkiss RS: Multiple triggers of cell death in sepsis: death receptor and mitochondrial-mediated apoptosis. FASEB J 2007, 21:708-719.

14. Peck-Palmer OM, Unsinger J, Chang KC, Davis CG, McDunn JE, Hotchkiss RS: Deletion of MyD88 markedly attenuates sepsisinduced T and B lymphocyte apoptosis but worsens survival. $J$ Leukoc Biol 2008, 83:1009-1018. 